\title{
The Standard of Anglo-Saxon Silver Pennies
}

\author{
By Ernest A. Smith
}

$\mathrm{T}^{\mathrm{H}}$ HE Department of Coins of the British Museum was considerably enriched some time ago by the valuable collection of Early English coins, bequeathed by the late Mr. T. G. Barnett, of Birmingham, which includes some five hundred silver pennies of various Anglo-Saxon kingdoms. These begin with a series of Mercia, including fine portrait coins of Offa (A.D. 758-796) of workmanship unrivalled until the reign of Henry VII, and the still rarer portrait coin of his queen Cynethryth, the only queen to appear on coins until Mary Tudor. In describing this collection, Mr. J. Allen ${ }^{1}$, keeper of the Coin Depart. ment, points out that "the historical value of the Anglo-Saxon coinage lies in the fact that it records rulers otherwise unknown, illustrates by its mints the rise and fall of Kingdoms, and particularly well illustrates the struggle with the Vikings and Danes". Apart, however, from their undoubted historical value, the large number of Anglo-Saxon pennies included in the collection is of special interest as, incidentally, it raises afresh the question of the fineness of the silver coinage used at that period, as Anglo-Saxon and Anglo-Norman coins are believed to have been made of the same alloy as that now known as sterling silver. This contains 92.5 per cent of silver, and has been the legalized standard for the silver coinage and the manufacture of silver wares in Great Britain for a period now extending well over six hundred years.

This being so, it will not be without interest to consider briefly the available evidence in support of this belief, especially as there appears to be no lack of suitable material with which to confirm it.

During the past fifty or more years, very considerable numbers of Anglo-Saxon silver pennies have been brought to light by the spade. This is perhaps not surprising when we recall that "the increase of mints inaugurated by Aethelred II (866-871) was continued to the end of the AngloSaxon period, during all of which time there was a great output of coins, and throughout a general uniformity of style and fabric" (Gueber). A wonderful find was made as early as 1840, at Preston, when a leaden chest was discovered containing no less than 10,000 silver coins, and nearly 1,000 ounces of silver ingots. It is thought to have been the treasure chest of the Danes who were defeated there in 911 . Two years earlier, in 1838, some 550 coins were dug up at Gravesend, Kent; and in more recent years smaller lots have been brought to light from time to time. Doubtless some of these eventually found their way into the melting pot, but in spite of this, many excellent specimens of Anglo-Saxon coins and silver ware are to be found in the British Museum and other museums of the country. It would appear, however, that up to the present, very few of these coins have been subjected to chemical analysis in order to determine their composition, a method of investigation that is now taking such a prominent place in all modern archæological research. Such few analyses as have been published seem to indicate that the composition aimed at by the Anglo-Saxon coiners was of the nature of a definite standard, which corresponded more or less to the sterling silver of more modern times. Thus, a few coins issued before the Norman Conquest, assayed by the late Sir W. C. Roberts-Austen ${ }^{2}$, chemist of the Royal Mint, gave the following results in regard to silver content. A coin of Burgred, King of Mercia (A.D. 852-874) contained only $33 \cdot 2$ per cent of silver, whilst one of Ethelred (A.D. 978-1016) was found to contain $91 \cdot 84$ per cent of silver, and was probably intended to represent the old standard of England, 92.5 per cent. A coin of Canute (A.D. 1016-1035) proved to be of the standard $93 \cdot 1$ per cent silver, and Roberts-Austen considered was clearly intended to represent the old standard. A coin of William the Conqueror was found to contain $92 \cdot 3$ per cent of silver, and was therefore of sterling quality. Unfortunately, no analyses of Anglo-Saxon silver wares appear to have been made, or if made, have not been published.

At first sight there may not appear to be very much agreement between the figures quoted, but in considering these compositions, it must not be overlooked that the early silver melters were not conversant with the scientific casting technique adopted at the present time to ensure uniformity of composition. Also they had no knowledge of the segregation that invariably takes place when silver-copper alloys solidify, and gives rise to irregularities of composition.

In regard to the adoption of this somewhat peculiar silver standard, Roberts-Austen has pointed out that, in the case of both the gold and silver currency of Great Britain, the adjustment of the relative proportions of the precious and the base metals was undoubtedly guided by the particular system of weights used. In the case of the silver coinage, the fineness of alloys of this metal has from very early times been computed by divisions of the troy pound, which is said to have 
been derived from the Roman weight of $5759 \cdot 2$ grains, the 125th part of the large Alexandrian talent, this weight, like the troy pound, having been divided by the Romans into twelve ounces.

There seems to be little doubt, therefore, that there is a distinct connexion between Roman and modern coins and plate, which suggests that the sterling silver was most probably introduced by the Roman coiners. Both Roman and Anglo-Saxon coins and silver wares were undoubtedly made from silver obtained from argentiferous lead by the cupellation process, to which more or less copper was intentionally added to give greater hardness to the metal to enable it better to withstand wear. That the Romans were skilful in conducting the cupellation process is proved by the high percentage of silver contained in many of their earlier issues of coins for which this silver was employed. Gowland ${ }^{3}$ has shown that the coins of the Romans, especially during the periods of the Republic, and the Empire up to the time of Nero, and again, with a few exceptions from Constantine to Justinian, frequently contained 98-99 per cent of silver. Much lower percentages, as for example 95 and less, indicate the intentional addition of copper. Some Roman silver coins of the first three centuries, found at Baden-Baden in 1825, when analysed showed a silver content varying from $91 \cdot 3$ down to as low as 50.5 per cent silver. Some of the higher quality coins had the following percentages of silver :

$\begin{array}{llll}\text { Tragan } & \text { (A.D. 98-117) } & 89 \text { per cent silver } \\ \text { Hadrian } & \text { (A.D. 117-138) } & 88 \cdot 25 \quad, \\ \text { Antoninus Pius } & \text { (A.D. 138-161) } & 91 \cdot 3 & ,\end{array}$

A coin of the Triumvir Antoninus (31 B.c.) had almost the same composition as British silver coins, as it contained 92.5 per cent of silver, and 7.1 per cent of copper, the remainder being gold and lead.

The differences shown in these figures are no doubt partly accounted for by the fact that the Romans adopted the method of casting their coins for the sake of cheapness and speed, and in consequence greater irregularities in composition are to be expected than in coins cut from sheet metal.

In this connexion also the assays of Roman silver objects in the British Museum, made by Gowland $^{3}$, are of considerable interest. They gave the following percentages of silver: Spoon, $95 \cdot 64$; dish, $94 \cdot 30$; dish, 92.50 ; rim of vessel, 95.52 ; bottom of another vessel, 94.90 ; patea, $95 \cdot 15$; large dish, 95.09.

As Gowland remarks, "in these assays the proportion of silver present ranges from $92 \cdot 5$ to $95 \cdot 6$ per cent, which would almost seem to indicate that this composition was aimed at by the Romans for what may be termed silver plate, and was of the nature of a definite standard."
The above data are of extreme interest, and although few in number, and not conclusive, they are sufficient to indicate without much doubt that the origin of sterling silver belongs to a much more remote date than is generally supposed. It is a common belief that the introduction of sterling silver dates only from 1300 , when it was first legalized as the quality of silver to be used for silversmiths' work. But in the earliest known accounts in which the standard of fineness is mentioned, it is always spoken of as the 'old standard of England', or as 'Easterling silver', thus showing that it had been in use for a considerable time prior to the passing of the Act. As already stated, the coinage of William the Conqueror was of this standard, which may therefore be said to have been in existence, without much interruption, from that time until the present day. Here it may be stated that opinions differ as to the origin of the term sterling, but the explanation found in the oldest records, and now very generally accepted, is that it is derived from the Germans, who were termed Easterlings by the English, from the fact that they lived 'eastward'. The money made by the German coiners was famous through. out Europe for its good quality, and it is said that German melters were fetched over in the twelfth century to improve the British coinage, which at that time had become somewhat debased. The coins made by these melters was termed Easterlings money by the English, but in the course of years, with the propensity for clipping long words, the first two letters were eventually dropped, and thus the alloy became known as sterling silver.

There is little doubt that silver of sterling standard was also used at a very early date for the production of silver wares, and it was only when fraudulent practices increased in their production that it was legalized to protect the honest craftsman and public alike.

The question of its origin is one of more than passing interest, as it concerns an alloy which is produced in considerable quantities annually, and has long been accepted as the most suitable standard for silversmiths' work not only in this country but also in America and elsewhere.

Now that the importance and value of chemical analysis as an indispensable aid to archæological research is being more generally recognized, it is to be hoped that further analyses of AngloSaxon coins and silver objects will be made, so that fresh light may be thrown on this interesting question.

\footnotetext{
${ }^{1}$ Brit. Mus. Quart., 10, 124 (March, 1936).

"Cantor Lectures on "Alloys used for Coinage", Roberts-Austen, J. Roy. Soc. Arts (1884).

"The Metais in Antiquity", W. Gowland. Royal Anthropological Institute of Great Britain and Ireland. 1912.
} 